GEOGRAFICKÝ ČASOPIS / GEOGRAPHICAL JOURNAL 71 (2019) 1, 3-14

DOI: https://doi.org/10.31577/geogrcas.2019.71.1.01

\title{
CAN EASTERLIN'S PARADOX BE APPLIED \\ TO THE DEVELOPMENT OF SATISFACTION WITH LIFE OR DOES THE EXPLANATION LIE IN CULTURAL GEOGRAPHICAL CHARACTERISTICS?
}

\author{
František Murgaš* \\ * Technical University in Liberec, Faculty of Science, Humanities and Education, Department of Geography, \\ Studentská 2, 46117 Liberec, Czech Republic, frantisek.murgas@tul.cz
}

\begin{abstract}
Can Easterlin's paradox be applied to the development of satisfaction with life or does the explanation lie in cultural geographical characteristics?

This paper is focused on the development of satisfaction with life, as declared by the inha-bitants of the Czech Republic in a long-term (2003 - 2015) and continuous questionnaire survey. In order to explain this development, we made correlations between the development satisfaction with life with the development of relevant economic variables such as wages and gross domestic product. Our objective is to refute or confirm Easterlin's paradox through correlations with wages and GDP development. The analysis of the development of satisfaction with life has revealed surprising findings; their possible explanation lies in Easterlin's paradox and geographical differentiations of cultural characteristics.
\end{abstract}

Key words: satisfaction of life, quality of life, Easterlin's paradox, wages, regions of the Czech Republic, cultural geography

\section{INTRODUCTION}

Scientists from the former socialist countries of Central and Eastern Europe, which were initially referred to as transitory and later as post-transitive countries, have examined the quality of life (Matutinović 1996, Ira and Andráško 2007, Kačmárová 2007, Jakubcová et al. 2016 and Murgaš and Klobučník 2016). Their advantage as insiders is a thorough knowledge of the situation. On the other hand, scientists from the West write about the quality of life in these countries too (Graham and Werman 2017). Alber et al. (2008), editors of the Handbook of Quality of Life in the Enlarged European Union, dealt with the quality of life in these former socialist countries. The benefits of a viewpoint from the other side of the former Iron Curtain include distance and perspective. Our paper is focused on the development of satisfaction with life in one of the most developed and richest countries in Central and Eastern Europe - the Czech Republic.

An important part of the concept of quality of life is satisfaction with life, related to one of two dimensions, is well-being. When we evaluate the quality of our lives, we evaluate satisfaction with it. In this context, Gatrell and Elliot (2015, p. 167) state 'life is not just what is, it's also what we think it is.' Satisfaction with life is understood 'as a whole' (van der Lippe 2014). In this paper we analyse the long-term development of satisfaction with life on a regional level in the Czech Republic, i.e. in a certain space, between $2003-2015$, and thus over time. The findings raise the question: how is this development explainable?

In recent years, a part of the quality of life research has taken the form of a debate concerning the validity or invalidity of Easterlin's paradox. The American economist's statement (Easterlin 1974) is one of the most frequently cited findings 
related to the quality of life. Pacione (2003) has a similar opinion, that satisfaction with life is not a function of material wealth - he calls it the "paradox of affluence." Some authors (e.g. Deaton 2007, Stevenson and Wolfers 2008 and Sacks et al. 2010) refute Easterlin's statements with correlations. Veenhoven and Vergunst (2013, p. 19) called Easterlin's paradox “Easterlin's illusion." Easterlin is still convinced that there is an absence of a 'long-term correlation between economic growth and happiness' and this belief is also based on correlations (Easterlin and Angelescu 2012 and Easterlin 2016). According to Oishi and Kesebir (2015), Easterlin's paradox can be partly explained by income inequality. Easterlin's findings are confirmed by other authors (e.g. Graham 2010 and Smith 2014) who consider Easterlin's paradox to be significant. How could this situation have happened? Veenhoven and Vergunst (2013) suggest the answer - Easterlin speaks about financial satisfaction, they speak about satisfaction with life. It means that everyone is talking about something else, so comparison is not meaningful.

Our paper is focused on satisfaction with life, declared by the inhabitants of the Czech Republic in a long-term and continuous (2003 - 2015) questionnaire survey. Wages in this country are the most important source of prosperity for the population, and in terms of their impact on satisfaction with life they are considered to be the primary variable in the public arena.

In terms of the impact on satisfaction with life, the GDP produced is a secondary variable that is reflected in wage growth over the long term. The regions are administrative units on a NUTS 3 level, from a geographic point of view they represent the basic unit in the assessment of regional differences in the Czech Republic (Blažek and Csank 2007). In this paper, we focused on them because satisfaction with life data is obtained on this hierarchical level. This data comes from the Public Opinion Research Centre of the Institute of Sociology at the Czech Academy of Sciences (2016) - (Centrum pro výzkum veřejného mínění, hereafter known as the CVVM).

Since 2003, the CVVM has been organizing the regional research of satisfaction with life ten times a year, with a sample group of more than one thousand respondents.

The answer to the question: 'How satisfied are you with your life?' has been considered for satisfaction with life. This question is based on the understanding of satisfaction 'as a whole', thus becoming the dimension of the quality of life. Research has been ongoing since 2003, the selection of respondents aged over 15 is a quota sample. Quotas: Region (oblast NUTS 3), size of place of residence, sex, age education.

We set two goals in the paper. The first one is the analysis of the long-term development of satisfaction with life on a regional level in the Czech Republic from 2003 to 2015. During this period, the development was not continuous but interrupted by the emergence of the US mortgage crisis, which quickly turned into an economic crisis and hit virtually the entire West. For this reason, although we are focusing on the development of a period between the years 2003 and 2015 on the one hand; on the other hand, we also feel that it is made up of two different periods. The second goal is to refute or confirm Easterlin's paradox through correlation between the development of satisfaction with life with wage and GDP developments. 
In connection with this objective, we have produced the hypothesis: in longterm development, the satisfaction with life of the Czech Republic's inhabitants on a regional level will grow directly in line with the growth of wages, which will mean the refutation of Easterlin's paradox.

\section{THEORETICAL BACKGROUND}

As we have already mentioned, satisfaction with life is a part of the concept of quality of life, and therefore its description needs to begin with a sketch of the conceptualisation of quality of life. In its formulation, we base it on the key findings as follows:

- Quality of life is holistic, it consists of two dimensions: subjective (wellbeing) and objective (quality of place, Murgaš and Klobučník 2016). It has two levels - individual and societal.

- A reference point to which the concept of quality of life relates, is the concept of the good life (Michalos and Robinson 2012 and Veenhoven 2013) which is lived in a good place (Murgaš 2016).

- When satisfaction with life is good, it is well-being, while when it is not the case, it is ill-being. Even if well-being is the more important of the two dimensions, it is not a quality of life itself. The meaning of quality of life concerns well-being and quality of place and these are its dimensions.

- Satisfaction with life is what one assesses when answering the question of how to evaluate your life as a whole. Well-being or ill-being is an expression of satisfaction with life. Satisfaction with life is the content of quality of life and its scale is long-term.

- Happiness is a short-lived emotional state in which a person can enjoy the greatest possible fulfilment of their expectations. When we measure satisfaction with life on the Cantril scale from 0 to 10, happiness refers to number 10; or 9 and 10 - 'very satisfied' on the Likert scale. As the feeling of happiness fades away, it then becomes satisfaction with life.

There is not a general consensus about what satisfaction with life is, as there is no general agreement about anything that is related to the concept of quality of life or related concepts. Diener and Lucas (1999) understand satisfaction with life as one of three parts of well-being, along with a pleasant and unpleasant affect. Von Humboldt et al. (2014, p. 631) state that 'Satisfaction with life refers to the overall cognitive appraisal of one's subjective well-being, a comparison reflecting the perceived discrepancy between one's aspirations and achievement.'

Satisfaction with life is a cognitive construct, unlike happiness which is an affective construct (Sirgy 2012 and Hall 2014). These two constructs only overlap by forty to fifty percent. According to some authors it is an even lower number, or they do not overlap at all. The definition of satisfaction with life (Sirgy 2012, pp. 36-37) is based on three components: Subjective well-being is an enduring (longterm) affective state that is made of a composite of three components: (a) actual experience of happiness or cumulative positive affect (joy, affection, pride, etc.) in salient life domains, (b) actual experience of depression or cumulative negative affect (sadness, anger, guilt, shame, anxiety, etc.) in salient life domains, and (c) evaluations of one's overall life or evaluations of salient life domains. 
Table 1 contains the substance of three components of subjective well-being. It shows three distinctions: (1) positive - negative, (2) affective - cognitive, and (3) short term - long term. Diener and Lucas (1999) understand satisfaction with life as one of three parts of well-being, along with a pleasant and unpleasant affect.

Tab. 1. The underlying construct of the various components of subjective well-being

\begin{tabular}{cll}
\hline \multicolumn{1}{c}{ Affective } & \multicolumn{1}{c}{ Cognitive } \\
\hline Positive & $\begin{array}{l}\text { Cumulative pleasant emotions (short } \\
\text { term) and feelings of happiness (long } \\
\text { term) }\end{array}$ & $\begin{array}{l}\text { Positive evaluation of life events (short } \\
\text { term) and life domains (long term) }\end{array}$ \\
Negative & $\begin{array}{l}\text { Cumulative unpleasant emotions (short } \\
\text { term) and feelings of depression (long } \\
\text { term) }\end{array}$ & $\begin{array}{l}\text { Negative evaluation of life events (short } \\
\text { term) and life domains (long term) }\end{array}$ \\
\hline
\end{tabular}

Source: Sirgy (2012).

\section{DATA AND RESULTS}

We know the measurement of satisfaction with life - Satisfaction with Life Scale (SWLS) - on the 7-point scale (1 - strongly disagree to 7 - strongly agree) whose authors are Diener et al. (1985). In the paper, we undertook a quantification of satisfaction with life on the 5-point Likert scale (1 - strongly dissatisfied to 5 strongly satisfied) which was used in the Czech Republic by CVVM (2016).

Table 2 shows changes in the development of satisfaction with life in 2003, 2009 and 2015 for each category of the Likert scale for all regions of the Czech Republic. It follows that satisfaction with life slightly increased in this 13 year period: in the category 'very satisfied' by $4 \%$, 'satisfied' by $1 \%$ and there was a $1 \%$ decrease in the category satisfied/dissatisfied. There were no changes in the categories 'dissatisfied' and 'very dissatisfied'.

During the period 2003 - 2015, satisfaction with life in the Czech Republic in some cases increased, in others decreased, but always slightly in percentage. During the period under review, satisfaction with life stagnated. Tab. 3 shows a quantification of wage and GDP development over the same period 2003-2015. As expected, in the Czech Republic, itself a successful post-transitory country, both variables grew by about $60 \%$, with wage growth ranging from $52 \%$ (Moravian-Silesian Region) to $107 \%$ (Prague) and GDP growth in the range of 30\% (Karlovy Vary Region) to $71 \%$ (Zlín Region).

It is possible to state other important finding. In 2015 compared with 2003, the average monthly wage and GDP in the Czech Republic regions significantly increased. Because satisfaction with life during the period under review stagnated, there is the hypothesis: in long-term development, satisfaction with life of Czech inhabitants on a regional level will grow directly proportional to wage growth, which will mean the refutation of Easterlin's paradox - it wasn't confirmed. 
GEOGRAFICKÝ ČASOPIS / GEOGRAPHICAL JOURNAL 71 (2019) 1, 3-14

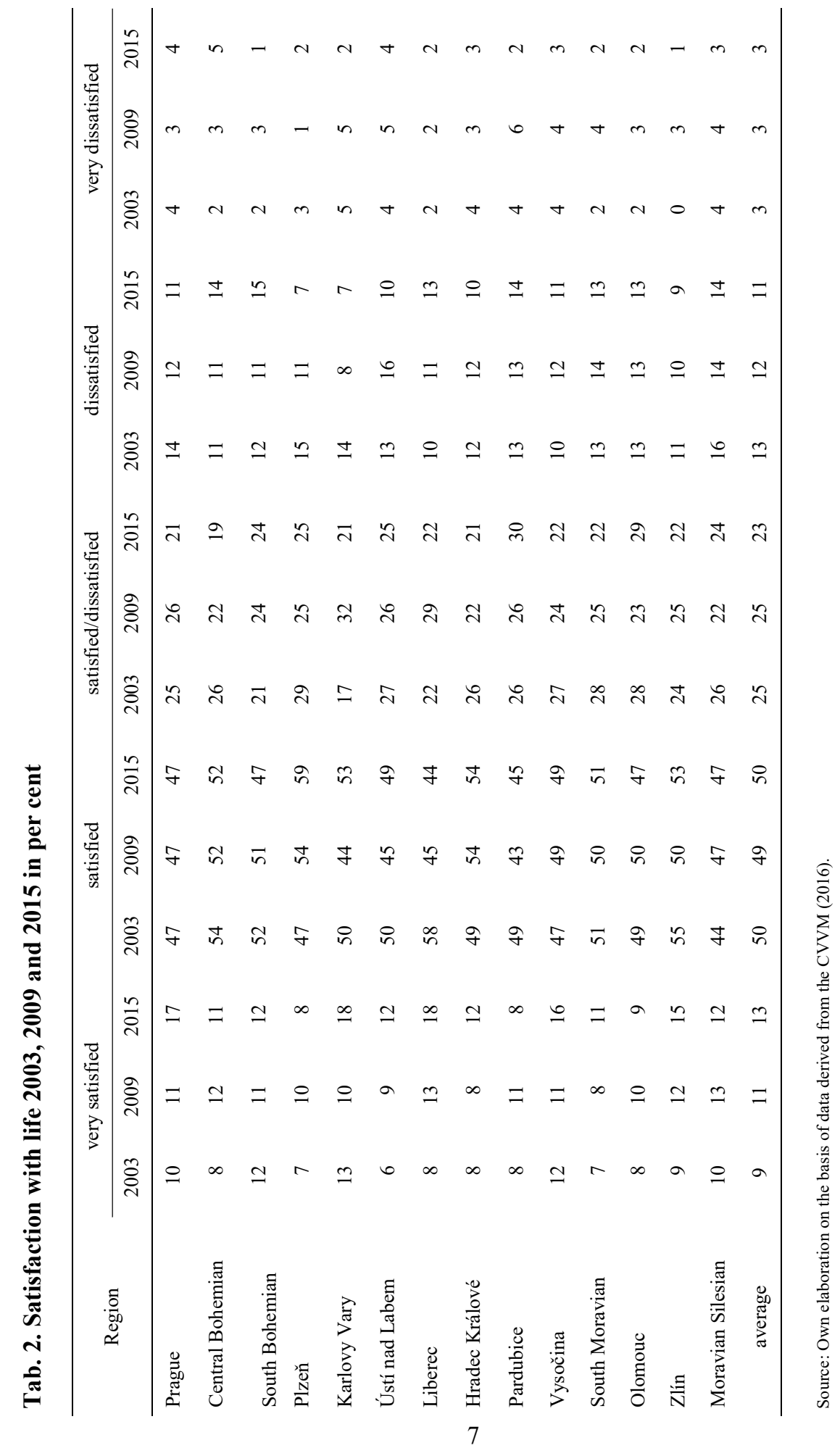


Tab. 3. Average monthly wage and GDP per capita in Czech regions in 2003, 2009 and 2015

\begin{tabular}{|c|c|c|c|c|c|c|c|c|}
\hline \multirow[b]{2}{*}{ Region } & \multicolumn{4}{|c|}{ Avarage monthly wage in CZK } & \multicolumn{4}{|c|}{ GDP per capita in thousands CZK } \\
\hline & 2003 & 2009 & 2015 & $\begin{array}{c}2015 \\
2003=100\end{array}$ & 2003 & 2009 & 2015 & $\begin{array}{c}2015 \\
2003=100\end{array}$ \\
\hline Prague & 21114 & 30028 & 35385 & 207 & 579 & 806 & 887 & 152 \\
\hline Central Bohemian & 17069 & 21972 & 28135 & 165 & 264 & 338 & 40 & 151 \\
\hline South Bohemian & 16206 & 20319 & 25816 & 159 & 247 & 319 & 362 & 146 \\
\hline Plzeň & 16781 & 21864 & 24327 & 163 & 259 & 338 & 404 & 156 \\
\hline Karlovy Vary & 15541 & 19450 & 24565 & 158 & 225 & 274 & 291 & 130 \\
\hline Ústí nad Labem & 16420 & 20850 & 25519 & 155 & 228 & 307 & 324 & 146 \\
\hline Liberec & 15826 & 20426 & 26379 & 167 & 224 & 281 & 335 & 149 \\
\hline Hradec Králové & 15944 & 20527 & 23644 & 161 & 241 & 323 & 378 & 157 \\
\hline Pardubice & 15933 & 19887 & 25489 & 160 & 232 & 303 & 349 & 150 \\
\hline Vysočina & 15650 & 20037 & 25616 & 164 & 227 & 302 & 354 & 155 \\
\hline South Moravian & 15626 & 21703 & 27506 & 176 & 252 & 350 & 425 & 169 \\
\hline Olomouc & 15589 & 19926 & 25215 & 162 & 214 & 279 & 340 & 159 \\
\hline Zlín & 15543 & 19478 & 24979 & 161 & 222 & 316 & 381 & 171 \\
\hline Moravian-Silesian & 17018 & 21136 & 25956 & 152 & 210 & 303 & 358 & 170 \\
\hline Czech Republic & 17516 & 22663 & 28152 & 161 & 275 & 374 & 432 & 157 \\
\hline
\end{tabular}

Source: Own elaboration on the basis of data from the Czech statistical office (2016a and 2016b).

\section{DISCUSSION}

Satisfaction with life between 2003 - 2015 on a regional level, surveyed ten times a year on a sample of more than a thousand respondents stagnated with the current increase in average wage and GDP. Therefore, the question arises: Why does the satisfaction with life of Czechs stagnate when prosperity increases? Does that mean that the Easterlin paradox is true? Yes, but this may not be the only explanation for the development of satisfaction with life. Czech sociologist Hamplová (2015), in her monograph Why We Need Family, Work and Friends (in Czech), states that behind the lower values of declared Czechs' satisfaction with life, there is a preference of the middle values on a chosen scale and the uniqueness of the declared highest level of satisfaction. The CVVM (2016) surveyed satisfaction with life on a 5-point scale, very satisfied - very dissatisfied. 
Many years have passed since the formulation of Easterlin's paradox, which has brought, amongst other things, the knowledge of increasing complexity and the interconnection of the concept of quality of life. In addition, what's useful as the "problem" of the validity or invalidity of Easterlin's paradox, is the question - what does affect the quality of life? According to the World Happiness Report 2016, Danes are the happiest people in the world (Helliwell et al. 2016). Are they happy because of their "hygge" ? Will Bulgarians who are - according to the same report - the least happy nation in present Europe, be as happy as Danes when they also start living hygge? I think neither Bulgarians nor any other nation will live hygge, because lifestyle is non-transferable as a result of a long-term development. It can be imitated but not fully achieved. In examining the quality of life, there is a general agreement with the fact that there are individualistic and collectivistic nations. Those are cultural characteristics. The way of life (Kubátová 2010) identifies it with lifestyle) is a part of culture (this is how we get to the relationship of culture and quality of life, Diener and Suh 2000, Rice and Steele 2004). Rodriguez de la Vega (2015) in his analysis states that the quality of life is 'culturally rooted', or 'culturally constructed.'

Hofstede et al. (2010) deal with culture and its relation to quality of life and Hofstede (2011), defines it as 'Culture is the collective programming of the mind that distinguishes the members of one group or category of people from others' (Hofstede 2011, p. 3). According to him, individual cultures are specific, which makes it possible to compare the general tendencies of the behaviour of people who belong to them. Hofstede et al. (2010) identified six dimensions of culture and they were used to create a 6D culture model. This allowed them to evaluate dozens of countries in the world. The rating of the Czech Republic (Hofstede Insights 2018a) and Denmark (Hofstede Insights 2018b) is in tab. 4. By transposition of the cultural dimension of quality of life into physical space, we reach the sphere of cultural geography.

The definitions of cultural geography are different. According to maximalist understanding, the whole of human geography is cultural geography, because everything that man does is culture. It is not easy to define cultural geography, because it is not easy to define what culture is. In our opinion, cultural geography studies the spatial differentiation of a wide range of cultural expressions. In relation to the quality of life from this scale, lifestyle comes to the foreground.

Denmark and Czech Republic are comparable in size, have a relative location in the proximity of a large country - Germany, but not by history, geographical location, language and lifestyle. The answer to the question - which one out of the six cultural dimensions has what kind of impact on the quality of life? - is difficult. Hofstede (2011) states the dimension of masculinity - femininity as one that is related to the quality of life. According to him, Denmark is a feminist society, the balance between life and work is important for its citizens. The determining values in society are caring for others and quality of life, while a (good) quality of life is the sign of success. The Czech Republic is a masculine society that is competitive and success oriented. People live there in order to work.

\footnotetext{
${ }^{1}$ Hygge - is a way of life in Denmark, based on enjoying little things like sitting with your family or with friends in a cosy environment. Hygge is considered to be the main reason for the fact that Danes are the happiest people in the world (Wiking 2017).
} 
Tab. 4. Cultural dimensions, values obtained by the Czech Republic and evaluation of the situation in the Czech Republic

\begin{tabular}{|c|c|c|c|c|}
\hline $\begin{array}{c}\text { Cultural } \\
\text { Dimensions }\end{array}$ & Value & Czechia(CR) & Value & Denmark (DK) \\
\hline $\begin{array}{c}\text { Power } \\
\text { Distance }\end{array}$ & 57 & $\begin{array}{l}\text { The CR has a relatively high score on this } \\
\text { dimension. This means it is a hierarchical } \\
\text { society. People accept a hierarchical order in } \\
\text { which everybody has a place and which } \\
\text { needs no further justification }\end{array}$ & 18 & $\begin{array}{l}\text { With a score of } 18 \text { points, this matches perfectly } \\
\text { with what many foreigners in DK express: Danes } \\
\text { not lead, they coach and employee autonomy is } \\
\text { required. }\end{array}$ \\
\hline $\begin{array}{l}\text { Uncertainty } \\
\text { Avoidance }\end{array}$ & 74 & $\begin{array}{l}\text { Countries exhibiting high uncertainty Avoid- } \\
\text { ance maintain Rigid codes of belief and } \\
\text { behaviour and are intolerant of un orthodox } \\
\text { behaviour and ideas. In these cultures there is } \\
\text { an emotional need }\end{array}$ & 23 & $\begin{array}{l}\text { This means that that Danes do not need a lot } \\
\text { of structure and predic-tability in their work life. } \\
\text { Plans can change overnight, new things pop up } \\
\text { and the Danes are fine with it It is a natural part } \\
\text { of their work life. }\end{array}$ \\
\hline $\begin{array}{l}\text { Individualism } \\
\text { vs. Collectivism }\end{array}$ & 58 & $\begin{array}{l}\text { In CR with a score of } 58 \text { is an individualistic } \\
\text { society. This means there is a high preference } \\
\text { for a loosely-kit social framework in which } \\
\text { individuals are expected to take care of } \\
\text { themselves. }\end{array}$ & 74 & $\begin{array}{l}\text { DK is an individualistic society. This means there } \\
\text { is a high preference for a loosely-kit social } \\
\text { framework in which individuals are expected to } \\
\text { take care of themselves. }\end{array}$ \\
\hline $\begin{array}{c}\text { Masculinity } \\
\text { vs Femininity }\end{array}$ & 57 & $\begin{array}{l}\text { CR is a Masculine society. In masculine } \\
\text { countries people "live in order to work". } \\
\text { The society will be driven by competition, } \\
\text { achievement and success, with success being } \\
\text { defined by the winner / best in field. } \\
\text { Managers are expected to be decisive and } \\
\text { assertive. }\end{array}$ & 16 & $\begin{array}{l}\text { DK is a feminine society. A low score (Feminine) } \\
\text { on the dimen-sion means that the dominant } \\
\text { values in society are caring for others and quality } \\
\text { of life. A femi-nine society is one where quality } \\
\text { of life is the sign of success and standing out } \\
\text { frame the crowd is not admirable }\end{array}$ \\
\hline $\begin{array}{l}\text { Long term } \\
\text { vs. Short term } \\
\text { orientation }\end{array}$ & 70 & $\begin{array}{l}\text { With a high score of } 70 \text {, Czech culture is } \\
\text { shown to be pragmatic. In this society people } \\
\text { believe that truth depends very much on } \\
\text { situation, context and time. }\end{array}$ & 35 & $\begin{array}{l}\text { A low score of } 35 \text { indicated that Danish culture is } \\
\text { normative. People in such societies have a strong } \\
\text { concern with establishing the absolute Truth, they } \\
\text { are normative in their thinking. }\end{array}$ \\
\hline $\begin{array}{l}\text { Indulgence } \\
\text { vs. Restraint }\end{array}$ & 29 & $\begin{array}{l}\text { The low score of } 29 \text { means that Czechs are } \\
\text { generally not indulgent. Societies with a low } \\
\text { score in this dimension have tendency to } \\
\text { cynicism and pessimism. }\end{array}$ & 70 & $\begin{array}{l}\text { DK is an indulgent country. People in societies } \\
\text { classified by a high score of indulgence generally } \\
\text { ex-hibit a willingness to realise their impulses and } \\
\text { desires with regard to enjoying life and having } \\
\text { fan. }\end{array}$ \\
\hline
\end{tabular}

Source: adapted from Hofstede Insights (2018a a 2018b).

On the one hand, we can agree with it, on the other hand, there is a real assumption that other dimensions of cultural geographical characteristics for example individualism/collectivism influence the level of happiness/quality of life/satisfaction with life. We assume a strong relationship between the quality of life and social capital and Hofstede does not deal with this.

The paper is focused on satisfaction with life in the Czech Republic regions. In this country, there are few works about lifestyle (Kubátová et al. 2015) or cultural geography on a regional level (Heřmanová and Chromý 2009). Therefore, it is difficult to compare lifestyle and culture with satisfaction with life.

\section{CONCLUSION}

In the paper we analysed the development of satisfaction with life from 2003 to 2015 in the regions of the Czech Republic. We set two objectives and one hypothesis - in long-term development, the satisfaction with life of the Czech Republic's 
inhabitants on a regional level will grow directly in line with the growth of wages, which will mean the refutation of Easterlin's paradox. This hypothesis was not confirmed.

According to all known findings up until now, satisfaction should have increased, and after reaching a certain level, should have started to stagnate or even decline in some regions. This is not the case in Czech regions. More appropriate spatial units for quality of life analysis would be districts, but only data for regions are available. Even with the indicative nature of the data, it can be stated that during the 13 years surveyed, satisfaction with life stagnated. We tried to answer why it is so, even when wages and GDP had been growing.

To a question put in the title of the article is the answer - in the development of satisfaction with life in the Czech Republic in the years 2003 - 2015 Easterlin's paradox applies, at the same time, however, reflected the impact of the characteristics of the cultural geographical situation in the Czech society.

The research was supported by the grant SGS Faculty of Science, Humanities and Education Technical University in Liberec No 21258.

The author would like to thank two anonymous opponents whose comments contributed to the improvement of the paper. The author also thanks Mr Christopher Muffett from the Department of the English Technical University of Liberec for reviewing the English text.

\section{REFERENCES}

ALBER, J., FAHEY, J., SARACENO, CH. (2008). Handbook of quality of life in the enlarged European Union. Oxon (Routledge).

BLAŽEK, J., CSANK, P. (2007). Nová fáze regionálního vývoje v ČR? Czech Sociological Review, 43, 945-966.

CZECH STATISTICAL OFFICE (2016a). A verage monthly gross wages and median of monthly gross wages, [Online]. Available https://vdb.czso.cz/vdbvo2/face s/index.jsf? page $=$ vystup-objekt\&pvo $=$ MZD001D320201C\&c=v33 $\quad$ RP2016\&u=v360 VUZEMI $100 \quad 3018$ [accessed 8 April 2018].

CZECH STATISTICAL OFFICE (2016b). Gross domestic product in the areas and regions, [Online]. Available https://vdb.czso.cz/vdbvo2/faces/en/index.jsf? page $=$ vystupobjektvyhledavani\&vyhltext $=$ hrub $\% \mathrm{C} 3 \% \mathrm{BD}+\mathrm{dom} \% \mathrm{C} 3 \% \mathrm{Alc} \% \mathrm{C} 3 \% \mathrm{AD}+$ produkt\&bkvt $=\mathrm{aHJ} 1 \mathrm{YsO}$ 9IGRvbcOhY 8OtIHByb2R1a3Q.\&katalog=all\&pvo=NUC05 -S1az4 [accessed 8 April 2018].

DEATON, A. (2007). Income, ageing, health and wellbeing around the world: evidence from the Gallup world pool. NBER Working Paper Series, Working paper 13317. Cambridge (The National Bureau of Economic Research). DOI: 10.3386/w13317.

DIENER, E., EMMONS, R. A., LARSEN, R. J., GRIFFIN, S. (1985). The satisfaction with life scale. Journal of Personality A ssessment, 49, 71-75. DOI: http://dx.doi.org/10.1207/ s15327 752j pa4901 13.

DIENER, E., LUCAS, $\bar{R}$. (1999). Personality and subjective well-being. In Kahneman, D., Diener, E., Schwarz, N., eds. Well-being: the foundation of hedonic psychology, New York (Sage), pp. 213-229, [Online]. Available https://internal.psychology.illinois.e du/ ed iener/Documents/Diener-Emmons-Larsen-Griffin 1985.pdf [accessed 30 March 2018].

DIENER, E., SUH, E. M. (2000). Culture and subjective well-being. Cambridge (MIT Press). 
EASTERLIN, R. A. (1974). Does economic growth improve the human lot? Some empirical evidence. In David, P. A., Reder, M. W., eds., Nations and households in economic growth essays in honour of Moses Abramowitz. New York (Academic Press).

EASTERLIN, R. A. (2016). Paradox Lost? USC-INET Research Paper No 16-02, [Online]. Available http://dx.doi.org/10.2139/ssrn.27140062. [accessed 7 April 2018].

EASTERLIN, R. A., ANGELESCU, L. (2012). Modern economic growth and quality of life: cross-sectional and time series evidence. In Land, K. C., Michalos, A. C., Sirgy, M. J., eds. Handbook of social indicators and quality of life research. Dordrecht (Springer), pp. 113-136.

GATRELL, A. C., ELLIOTT, S. J. (2015). Geographies of health. An introduction. Third Edition. Malden and Oxford (Wiley).

GRAHAM, C. (2010). More on the Easterlin Paradox: a response to wolfers, [Online]. Available https://www.brookings.edu/blog/up-front/2010/12/15/more-on-the-easterlinpara dox-a-response-to-wolfers/ [accessed 8 April 2018].

GRAHAM, C., WERMAN, A. (2017). Well-Being in the transition economies of the successor states of the former Soviet Union: the challenges of change. In Estes, R. J., Sirgy, M. J., eds. The pursuit of human well-being. The Untold History. Cham (Springer), pp. 493-522.

HALL, A. (2014). Concept of life satisfaction. In Michalos, A. C., ed. Encyclopedia of quality of life and Well-Being. Dordrecht (Springer), pp. 3599-3601.

HAMPLOVÁ, D. (2015). Proč potřebujeme rodinu, práci a prátele. Štěstí ze sociologické perspektivy. Praha (Fortuna Libri).

HELLIWELL, J., LAYARD, R., SACHS, J. (2016). World happiness report 2016, Update (Vol. I). New York (Sustainable Development Solutions Network).

HERMANOVÁ, E., CHROMÝ, P., et al. (2009). Kulturní regiony a geografie kultury: Kulturní reálie a kultura v regionech Česka. Praha (ASPI).

HOFSTEDE, G., HOFSTEDE, G. J., MINKOV, M. (2010). Cultures and organizations: software of the mind, 3rd edition. New York (Mc Graw-Hill).

HOFSTEDE, G. (2011). Dimensionalizing cultures: the Hofstede model in context, [Online]. Readings in Psychology and Culture, 2(1). https://doi.org/10.9707/23070919.1014. [accessed 24 April 2018]. DOI: https://doi.org/10.9707/2307-0919.1014.

HOFSTEDE INSIGHTS (2018a). Country Comparison, Czech Republic, [Online]. Available: https://www.hofstede-insights.com/country-comparison/czech-republic/. [accessed 24 April 2018].

HOFSTEDE INSIGHTS (2018b). Country Comparison, Denmark. [Online]. Available: https://www.hofstede-insights.com/country-comparison/denmark/. [accessed 24 April 2018].

IRA, V., ANDRÁŠKO, I. (2007). Kvalita života z pohl'adu humánnej geografie. Geografický časopis, 59, 159-179.

JAKUBCOVÂ, A., GREŽO, H., HREŠKOVÁ, A., PETROVIČ, F. (2016). Impacts of flooding on the quality of life in rural regions of Southern Slovakia. Applied Research in Quality of Life, 11, 221-237. DOI 10.1007/s11482-014-9363-x.

KAČMÁROVÄ, M. (2007). Osobnost', manželský stav a subjektívna pohoda seniorov. Československá psychologie, 51, 530-541.

KUBÁTOVÁ, H. (2010). Sociologie životního způsobu. Praha (Grada).

KUBÁTOVÁ, H., ZICH, F., ZNEBEJÁNEK, F., ANÝŽOVÁ, P., ROUBAL, O. (2015). Mezigenerační promény způsobu života na Hlučínsku. Praha (Slon).

MATUTINOVIĆ, I. (1998). Quality of life in transition countries: Central East Europe with special reference to Croatia. Social Indicators Research, 43, 97-119. DOI: https://doi.org/ 10.1023/A:1006818625202.

MICHALOS, A. C., ROBINSON, S. R. (2012). The good life: eighth century to third century BCE. In Land, K. C., Michalos, A. C., Sirgy, M. J., eds. Handbook of social indicators and quality of life research. Dordrecht (Springer), pp. 23-61.

MURGAŠ, F. (2016). Geographical conceptualization of quality of life. Ekológia (Bratislava), 35, 309-319. DOI: 10.1515/eko-2016-0025. 
MURGAŠ, F., KLOBUČNÍK, M. (2016). Municipalities and regions as good places to live: index of quality of life in the Czech Republic. Applied Research in Quality of Life, 11, 553-570. DOI: 10.1007/s11482-014-9381-8.

OISHI, S., KESEBIR, S. (2015). Income inequality explains why economic growth does not always translate to an increase in happiness. Psychological Science, 26, 1630-1638. DOI: $10.1177 / 0956797615596713$.

PACIONE, M. (2003). Urban environmental quality and human wellbeing - a social geographical perspective. Landscape and Urban Planning, 65, 19-30. DOI: 10.1016/S01692046(02)00234-7.

RICE, W., STEELE, B. J. (2004). Subjective well-being and culture across time and space. Journal of Cross-Cultural Psychology, 35, 633-647. DOI: https:// doi.org/10.1177/002202210427 0107.

RODRIGUEZ de la VEGA, L. (2015). The role of context and culture in quality of life studies. In Tonon, G., ed. Qualitative studies in quality of life. Dordrecht (Springer), pp. 37-52.

SACKS, D., STEVENSON, B., WOLFERS, J. (2010). Subjective well-being, income, economic development and growth. NBER working paper series, Working paper 16441. Cambridge (National Bureau of Economic Research).

SIRGY, M. J. (2012). The psychology of quality of life. Hedonic well-being, life satisfaction, and eudaimonia. Second Edition. Dordrecht (Springer).

SMITH, C. (2014). Easterlin paradox. In Michalos, A. E., ed. Encyclopedia of quality of life and well-being research. Dordrecht (Springer), pp. 1754-1757.

STEVENSON, B., WOLFERS, J. (2008). Economic growth and subjective well-being: Reassessing the Easterlin paradox. NBER working paper series, Working paper 14282. Cambridge (National Bureau of Economic Research). DOI: 10.3386/w14282.

THE INSTITUTE OF SOCIOLOGY OF THE CZECH ACADEMY OF SCIENCES, Public opinion research centre (2016). Our society 2011 - 2015 [data set] [online]. Ver. 1.0. Praha (Český sociálněvědní datový archiv, 2011-15). [27. 1. 2017]. DOI: 10.14473/ V1101-V1512.

VEENHOVEN, R. (2013). Notions of the good life. In David, S. A., Boniwell, I., Ayers, A. C., eds. The Oxford handbook of happiness. Oxford (Oxford University Press), pp. 161173.

VEENHOVEN, R., VERGUNST, F. (2013). The Easterlin illusion: economic growth does go with greater happiness. MPRA Paper No. 43983. Munich (Munich Personal RePEc Archive). DOI: 10.1504/IJHD.2014.066115.

van der LIPPE, T. (2014). Satisfaction with life as a whole. In Michalos, A. C., ed. Encyclopedia of quality of life and well-being. Dordrecht (Springer), pp. 5654-5656.

von HUMBOLDT, S., LEAL, I., PIMENTA, F. (2014). Living well in later life: the influence of sense of coherence, and socio-demographic, lifestyle and health-related factors on older adults' satisfaction with life. Applied Research in Quality Life, 9, 631-642. DOI: http://dx.doi.org/10.1007/s11482-013-9262-6.

WIKING, M. (2017). The little book of hygge: Danish secrets to happy living. New York (HarperCollins Publisher).

František Murga ̌

\section{MÔŽE BYŤ EASTERLINOV PARADOX APLIKOVANÝ NA VÝVOJ SPOKOJNOSTI SO ŽIVOTOM ALEBO JE VYSVETLENIE V KULTÚRNO GEOGRAFICKÝCH CHARAKTERISTIKÁCH?}

Významnou súčast'ou konceptu kvality života je spokojnost' so životom. Ked' hodnotíme kvalitu svojho života, hodnotíme spokojnost' s ním. Pozitívnym hodnotením kvality života je pohoda. Spokojnost' so životom je kognitívny konštrukt, na rozdiel od št'astia, 
ktoré je afektívny konštrukt (Sirgy 2012 a Hall 2014). Jedným z najznámejších konštatovaní súvisiacich s kvalitou života je, že po dosiahnutí určitej úrovne príjmov spokojnost' so životom nestúpa, v niektorých prípadoch dokonca klesá. Toto tvrdenie, známe ako Easterlinov paradox, v súčasnosti viacerí autori vyvracajú (napr. Deaton 2007, Sacks et al. 2010 a Veenhoven a Vergunst 2013).

Príspevok je zameraný na vývoj spokojnosti so životom deklarovanej obyvatel'mi krajov ČR v dlhodobom (roky 2003 - 2015) a kontinuálnom (desat'krát ročne) dotazníkovom prieskume. V snahe vysvetlit' tento vývoj sme analyzovali korelácie vývoja spokojnosti so životom s vývojom relevantných ekonomických premenných, ktorými sú mzda a hrubý domáci produkt. Ciel'om príspevku bolo na základe porovnania vývoja spokojnosti so životom na úrovni krajov ČR v rokoch 2003 - 2015 s vývojom miezd a HDP na osobu vyvrátit' alebo potvrdit' Easterlinov paradox.

Vývoj spokojnosti so životom sme analyzovali na základe dát Centra pre výskum verejnej mienky pri Sociologickom ústave Akadémie vied ČR. Zmeny vo vývoji spokojnosti so životom za roky 2003, 2009 a 2015 v jednotlivých kategóriách 5-stupňovej Likertovej škály vyjadruje tab. 2. Vyplýva $\mathrm{z}$ nej, že spokojnost' so životom za trinást' sledovaných rokov stagnovala. $\mathrm{V}$ tab. 3 je kvantifikácia vývoja miezd a HDP na osobu v rovnakom období rokov 2003 - 2015. Ako sa dalo očakávat', v ČR obidve premenné vzrástli asi o $60 \%$, pričom rast miezd sa pohyboval v rozpätí $52-71 \%$. Pretože spokojnost' so životom v sledovanom období stagnovala, hypotéza, že v dlhodobom vývoji bude spokojnost' so životom obyvatel'ov ČR na krajskej úrovni rást' priamo úmerne s rastom miezd, čo bude znamenat' vyvrátenie Easterlinovho paradoxu, sa nepotvrdila. Znamená to, že Easterlinov paradox platí? Áno, ale domnievame sa, že odpoved' je zložitejšia.

Česká sociologička Dana Hamplová vo svojej monografii Proč potřebujeme rodinu, práci a přátele konštatuje, že za nižšími hodnotami deklarovanej spokojnosti Čechov so životom je preferencia stredových hodnôt na zvolenej škále a ojedinelost' deklarovanej najvyššej miery spokojnosti (Hamplová 2015). Toto tvrdenie je kultúrna charakteristika, tým sa dostávame ku vzt'ahu kultúry a kvality života. Rodriguez de la Vega (2015) vo svojej analýze uvádza, že kvalita života je „zakorenená v kultúre“, resp. „kultúrne konštruovanác“. Kultúrou a jej vzt’ahom ku kvalite života sa zaoberajú Hofstede et al. (2010) a Hofstede (2011), podl'a nich jednotlivé kultúry sú špecifické, čo umožňuje porovnávanie všeobecných tendencií správania l'udí, ktorí k nim patria. Premietnutím kultúry do fyzického priestoru sa dostávame do sféry kultúrnej geografie. Podl'a maximalistického chápania celá humánna geografia je kultúrnou geografiou, pretože všetko, čo človek robí, je „kultúra“. Podla nášho názoru kultúrna geografia je štúdium priestorovej diferenciácie širokej škály prejavov kultúry. V tab. 4 uvádzame porovnanie CR a Dánska. Krajiny sú porovnatel'né svojou vel'kost'ou, relatívnou polohou v susedstve vel'kej krajiny - Nemecka, ale už nie dejinami, geografickou polohou, jazykom a spôsobom života. Odpovedat' na otázku, ktorá z dimenzií kultúrnej geografie má aký vplyv na kvalitu života, je zložité. Podl'a Hofstedeho je pre kvalitu života dôležitý rozmer maskulinita - femininita, domnievame sa že je ním aj individualizmus - kolektivizmus. Silný vzt’ah predpokladáme aj medzi kvalitou života a sociálnym kapitálom, ktorým sa Hofstede nezaoberá. Na otázku položenú v názve článku odpovedáme: Vo vývoji spokojnosti so životom v ČR v rokoch 2003 - 2015 platí Easterlinov paradox, zároveň sa však prejavuje aj vplyv charakteristík kultúrnej geografie českej spoločnosti. 